\title{
Nitrogen Metabolism and Microbial Protein Synthesis by Local Sheep Fed Diet Containing Hibiscus Leave Meal (HLM) with Different Direct-Fed Microbials (DFM) Supplementation
}

\author{
Risda Amelia Putri Nasution ${ }^{1}$, Sri Rahayu ${ }^{2}$ and Muhamad Bata ${ }^{2} *$ \\ ${ }^{1}$ Postgraduate Student, Faculty of Animal Husbandry Jenderal Soedirman University, 53122 Purwokerto, Indonesia \\ ${ }^{2}$ Department of Nutrition, Faculty of Animal Husbandry Jenderal Soedirman University, 53122 Purwokerto, Indonesia \\ *Corresponding author email: muhamadbata@yahoo.com
}

\begin{abstract}
The interaction of Hibiscus Leaf Meal (HLM) and Direct-Fed Microbials (DFM) supplementation on nitrogen metabolism and rumen microbial synthesis by local sheep was investigated. Thirty six male local sheep aged \pm 2 years, weight $28.01 \pm 2.61 \mathrm{~kg}$ were fed concentrate ( $3 \%$ of body weight) supplemented with HLM twice a day, amoniated rice-straw (ARS) supplemented with DFM were given ad-libitum were assigned randomly to nine treatment in an experiment of $3 \times 3$ factorial design. The first factor (P) was DFM were supplemented in ARS (P0=without DFM, P1=DFMAMS, and P2=DFMRK). Second factor (W) was the level of HLM supplementation in concentrate $(\mathrm{W} 0=0 \%, W 1=0.24 \%$ and $W 2=0.48 \%$ of DM consentrate. The study measured variables including nitrogen digestibility (ND), nitrogen retention (NR), microbial protein synthesis (MPS), and Efficiency of microbial protein synthesis (EMPS). There were significant interaction between DFM and HLM suplementation on MPS and EMPS. However, the interaction of ND and NR was non-existent. Based on polynomial graph, the most efficient MPS was achieved on combination between DFMRK and $0.23 \%$ HLM about $8.70 \mathrm{gN} /$ day. Despite the absence of interaction $(P>0.05)$ between DFM supplementation and HLM on KN and RN, DFM supplementation significantly affected $(P<0.01)$ Nitrogen metabolism (ND and NR). The treatment without DFM supplementation resulted the highest nitrogen metabolism (ND and NR). This study concludes that HLM without DFM suplementation positively impacted $\mathrm{N}$ Metabolism. Combination between $0.23 \%$ HLM and DFMRK resulted the most efficient Microbial Protein Synthesis.
\end{abstract}

Keywords : sheep, hibiscus, DFM, nitrogen-metabolism, microbial protein synthesis

Abstrak. Interaksi suplementasi Hibiscus Leaf Meal (HLM) dan Direct-Fed Microbials (DFM) terhadap metabolisme nitrogen dan sintesis mikroba rumen oleh domba lokal telah diteliti. Tiga puluh enam ekor domba lokal jantan umur \pm 2 tahun, bobot $28,01 \pm 2,61 \mathrm{~kg}$ diberi pakan konsentrat ( $3 \%$ bobot badan) ditambah HLM dua kali sehari, jerami padi amoniasi (JPA) ditambah DFM diberi ad-libitum ditetapkan secara acak terhadap sembilan perlakuan dalam percobaan desain faktorial $3 \times 3$. Faktor pertama $(P)$ adalah DFM yang dilengkapi dengan JPA (P0 = tanpa DFM, P1 = DFMAMS, dan P2 = DFMRK). Faktor kedua (W) adalah kadar suplementasi HLM dalam konsentrat ( $\mathrm{W} 0=0 \%, \mathrm{~W} 1=0,24 \%$ dan $\mathrm{W} 2=0,48 \%$ dari BK konsentrat. Variabel penelitian yang diukur meliputi kecernaan nitrogen (KN), retensi nitrogen (RN), sintesis protein mikroba (SPM), dan efisiensi sintesis protein mikroba (ESPM). Terdapat interaksi yang signifikan antara suplementasi DFM dan HLM pada SPM dan ESPM. Namun, interaksi KN dan RN tidak ada. Grafik polinomial, SPM yang paling efisien dicapai pada kombinasi antara DFMRK dan 0,23\% HLM sebesar 8,70 gN / hari. Meskipun tidak ada interaksi (P> $0,05)$ antara suplementasi DFM dan HLM pada KN dan RN, suplementasi DFM berpengaruh nyata $(P<0.01)$ Metabolisme Nitrogen (KN dan RN) Perlakuan tanpa suplementasi DFM menghasilkan metabolisme nitrogen ( $K N$ dan RN) tertinggi. Penelitian ini menyimpulkan bahwa HLM tanpa suplementasi DFM berpengaruh positif terhadap Metabolisme N. Kombinasi antara 0,23\% HLM dan DFMRK menghasilkan lebih banyak Sintesis Protein Mikroba yang efisien.

Kata kunci: domba, hibiscus, dfm, metabolisme nitrogen, sintesis protein mikroba

\section{Introduction}

Indonesia is a country with a large population in the world, and it is correlated with high demand of goods, including those from livestock industries, such as eggs, meat, and milk. Local sheep are alternative livestock as the meat source because they already adapt to tropical climate. Hence, the chances of increasing its productivity are widely open. The contribution of mutton vs total national ruminant meat production in the past 5 years is 
not significantly increased in numbers. The average contribution of mutton in 2014-2018 was only 7.34\% (Ditjennak, 2018). Elghandour et al. (2015) stated that improvement of productivity of local sheep can be achieved through feedlot system. It is carried out by providing high concentrated composition in certain period of time. This is because ruminants need a sufficient amount of protein for their needs which can be fulfilled from microbial proteins as the ruminal fermentation product (Putra et al., 2016). The most common obstacle in the use of high concentrated rations is acidosis incidence due to a fast decreased $\mathrm{pH}$ and changes in microbial ecosystems in the rumen (McAllister et al., 2011). To overcome this problem, an additive that functions as a buffer to maintain the $\mathrm{pH}$ of the rumen is needed so that rumen microbes can grow and act normally, this is marked by the high efficiency of nitrogen use and microbial protein production in the rumen.

The use of Hibiscus Leaf Meal (HLM) is expected to increase the efficiency of fermentation in the rumen through stabilization of rumen pH. Bata and Rahayu (2017) reported that small type of HLM leaves containing flavonoids improved rumen fermentation by manipulating rumen $\mathrm{pH}$. Flavonoid supplementation might be effective in improving rumen fermentation and reducing the incidence of rumen acidosis and bloat (Balcells et al., 2012; Seradj et al., 2014; Kalantar, 2018). Another obstacle in sheep production is limited crops farm. The use of Ammoniated Rice-Straw (ARS) is an attempt to replace forage as a source of crude fiber in ruminant. The purpose of ammoniation is to increase the quality of rice-straw. However, the release of NH3-N from urea-treated crop residues, such as rice straw has made the whole process unefficient and caused environmental pollution (Khan et al., 2004).

Direct Fed-Microbials (DFM) is a combination of several microbes or one living microbe that is orally supplemented to increase livestock productivity, the most commonly used DFM comes from bacteria, fungi, and yeast (Khan et al., 2016; Mutaqin et al., 2018). Either single or double strains of DFM have been used for 15-30 years with varying results (Buntyn et al., 2015; McAllister et al., 2011). Addition of DFM to ARS before being given to sheep may reduce $\mathrm{N}-\mathrm{NH} 3$ because the microbes in DFM can use it as a nitrogen source. Accordingly, the efficiency of nitrogen use in the rumen can be improved and increased microbial protein synthesis. Supplementation of DFM in ARS increase the palatability of ARS and Lactate Utilizing Bacteria (LUB) in the rumen also stabilize rumen $\mathrm{pH}$ (Seo et al., 2010). In the other hand, DFM supplementation in rumen is increasing the number of protozoa (Ghorbani et al., 2018 ; Krehbiel et al. 2003). This can lead to decreased microbial protein synthesis. Administration of saponins to the rumen could reduce protozoa which are predatory of bacteria so that it can increase microbial protein synthesis (Patra and Saxena, 2009). In relation to that, this study aims to determine the effect of the interaction between the use of DFM and HLM which contain saponins and flavonoids active ingredients on nitrogen metabolism and microbial protein synthesis in local sheep.

\section{Materials and methods}

The study was conducted in April-August 2018 in UD. Sapi Amanah Farm, Banyumas Regency, Indonesia. Chemical analysis was conducted in the Laboratory of Animal Nutrition and Feed, Faculty of Animal Husbandry, Jenderal Soedirman University, Indonesia. 
Table 1. Nutrient content of ammoniated rice-straw (ARS), ARS + DFM ${ }_{A M S}, A R S+D F M_{R K}$, concentrate and HLM

\begin{tabular}{|c|c|c|c|c|c|c|c|}
\hline \multirow{2}{*}{ Ingredients } & DM & Ash & $\mathrm{CP}$ & $\mathrm{EE}^{*}$ & $\mathrm{CF}$ & NFE & TDN \\
\hline & \multicolumn{7}{|c|}{ (\% DM) - } \\
\hline ARS & 29.06 & 26.29 & 7.63 & 1.56 & 33.41 & 33.19 & 46.65 \\
\hline$A R S+D_{A M S}$ & 26.56 & 25.43 & 7.58 & 1.56 & 36.09 & 33.19 & 46.65 \\
\hline$A R S+D F M_{R K}$ & 26.65 & 27.04 & 6.30 & 1.56 & 36.13 & 33.19 & 46.65 \\
\hline Concentrate & 83.76 & 10.75 & 9.08 & 13.36 & 25.81 & 43.08 & 74.58 \\
\hline HLM ** & 95.50 & 8.23 & 4.60 & 4.60 & 20.61 & 50.74 & 17.74 \\
\hline
\end{tabular}

*Hanum and Usman (2011); Hartadi et al. (2017)

**Bata and Rahayu (2017)

Note: ARS=Ammoniated Rice-Straw, HLM=Hibiscus Leaf Meal, DFM=Direct-Fed microbials, $\mathrm{DM}=$ Dry Matter, $\mathrm{CP}=\mathrm{Crude}$

Protein, $\mathrm{EE}=$ Ether Extract, NFE=Nitrogen-free Extract, $\mathrm{CF}=$ Crude Fiber, $\mathrm{TDN}=$ Total Digestible Nutriens

\section{Experimentals design and animals management}

Thirty-six local male sheep aged \pm 2 years (body weight $28.01 \pm 2.61 \mathrm{~kg}$ ) were assigned randomly to nine treatments in an experiment of $3 \times 3$ factorial design. All groups were fed ammoniated rice-straw (ARS) ad-libitum and concentrates $3 \%$ of body weight of sheep. The concentrate was fed twice at 07.00 am and at $15.00 \mathrm{pm}$. The time needed for this experiment was 26 days, adaptation of feed for 7-days, preliminary feed period for 14 -days and 5 -days for data collection. During the collection, the animals were kept in individual cage to ensure separation urine and feces. The ingredient of the concentrate used were cassava pulp, pollard, oil cake, coconut cake, soybean meal, molasses, dolomite, salt, urea, and mineral. The nutrient content of ARS, ARS supplemented $D_{\text {DFM }}$ AMS, ARS supplemented DFM RK, $_{\text {, }} \mathrm{HLM}$ and concentrate were presented in table 1.

Direct-Fed microbials (DFM) used in this study were $D_{F M}(P 1)$ produced by PT. AMS Korea with 17 kinds of microbes that are mostly bacteria with density $2.05 \times 108 \mathrm{CFU} / \mathrm{ml}$. Furthermore DFM $_{\mathrm{RK}}$ (P2) produced by PT. Banyumas Raya Indonesia contains 15 bacteria and Saccharomyces cereviseae with a density of $1.49 \times 107 \mathrm{CFU} / \mathrm{g}$ of bacteria and 4.50×104 $\mathrm{CFU} / \mathrm{g}$ of yeast.

The experiment was conducted in a completely randomized design (CRD) with $3 \times 3$ factorial design and four replications. The first factor (P) was DFM were supplemented in Ammoniated Rice Straw (ARS) (PO=without DFM, P1=DFM $M_{A M S}$, and $\left.P 2=D F M_{R K}\right)$. Second factor (W) was the level of HLM supplementation in concentrate (W0 $=0 \%$, $\mathrm{W} 1=0.24 \%$ and $\mathrm{W} 2=0.48 \%$ of DM consentrate). Combination of treatments were POWO=ARS without DFM+0\% HLM; POW1=ARS without DFM+0.24\% HLM; POW2=ARS without DFM+0.48\% HLM; P1W0=DFM AMS + concentrate without HLM; P1W1=DFM AMS $+0.24 \%$ HLM; $\mathrm{P} 1 \mathrm{~W} 2=\mathrm{DFM}_{\mathrm{AMS}}+0.48 \% \quad \mathrm{HLM} ; \quad \mathrm{P} 2 \mathrm{~W} 0=$ $D_{\mathrm{DFM}}+$ concentrate without HLM; $\mathrm{P} 2 \mathrm{~W} 1=$ $\mathrm{DFM}_{\mathrm{RK}}+0.24 \% \mathrm{HLM}$; and P2W2 $=\mathrm{DFM}_{\mathrm{RK}}+0.48 \%$ HLM.

Hibiscus/Waru leaves were collected from Cilacap District. The branches and leaves were separated then dried under the sun for 3-6 days. The dried leaves were pulverized into HLM using a grinding machine. The HLM was mixed into the concentrate according to the level, $0.24 \%$ and $0.48 \%$ from DM concentrate.

Rice-straw ammoniation used 5\% urea and $2.5 \%$ cassava powder as the source of fermentable carbohydrates. Water was added as much as $16 \%$ of the weight of rice straw as recommended by Bata et al., (2016), DFM sprayed directly to the ARS till blended well. ARS that has been sprayed DFM left one night before it is given to sheep next day.

The measured ariable measured were local sheep nitrogen metabolism according to method as recommended by Banerjee (1978). 
Microbial Protein Synthesis estimated were detected by Chen and Gomes (1995).

\section{Sample collection and chemical analysis}

The samples were collected with a total collection method according Cole and Ronning (1974). Chemical Analysis of DM, ash, crude fiber, and crude protein and $\mathrm{N}$ of faeces, feed offered and refused were carried out according to AOAC (2005). Urine protein analysis performed according to Bradford (1976). Microbial protein synthesis used colorimetric method according to Chen and Gomes (1995).

\section{Statistic analysis}

Data were subjected to analysis of variance (ANOVA) followed by orthogonal polynomials and HSD test (Steel and Torrie, 1999; Tukey, 1953).

\section{Results and Discussion}

\section{Dry matter intake (DMI) and nitrogen metabolism}

The results of the study used combination between DFM and HLM level by local sheep on nitrogen metabolism and DMI are summarized in the Table 2 and detailed on Table 3.
There were a significant interaction $(P<0.05)$ between P (DFM supplementation) and W (HLM level) by local sheep on DMI, but there were no interaction $(\mathrm{P}<0.05)$ on nitrogen metabolism (Table 2). The type of DFM had a significant effect $(P<0.01)$ on Nitrogen Retention (NR), Nitrogen Digestibility (ND), and also affected $(\mathrm{P}<0.05)$ on Net Nitrogen Utilization (NNU) and Biological Value (BV). The digestibility of N (ND), $N R, N N U$, and BV of sheep fed without DFM $(P 0)$ was higher $(P<0.05)$ than others.

The increase in HLM resulted in a different DMI on the addition of DFM and controls. In sheep that were not given DFM, the DMI increased with the HLM dose up to $0.26 \%$ and after that, an increase in the HLM level to the $0.5 \%$ dose caused a decrease in DMI. This was different from sheep who received DFM, the increase in the dose of HLM caused a decrease in DMI to a dose of 0.24 and thereafter increased as the HLM increased to a dose of $0.5 \%$. This difference in response might be due to the role of DFM in the rumen and one of them is the increase in the number of rumen protozoa (Ghorbani et al., 2018; Krehbiel et al. 2003).

Table 2. Dry matter intake (DMI), nitrogen metabolism at different of direct-fed microbials (DFM) and hibiscus leaf meal (HLM) levels

\begin{tabular}{cccccccc}
\hline \multicolumn{2}{c}{ Treatments } & \multicolumn{7}{c}{ Variable Response } \\
\cline { 2 - 8 } & W0 & NR (g/d) & ND (\%) & BV (\%) & NNU (\%) & DMI $(\mathrm{kg})$ & ARS:C \\
\hline \multirow{3}{*}{ P0 } & W1 & $9.12 \pm 1.55$ & $49.43 \pm 9.94$ & $94.12 \pm 1.56$ & $46.63 \pm 10.10$ & $1.04 \pm 0.07$ & $9: 91$ \\
& W2 & $8.24 \pm 1.17$ & $51.91 \pm 6.62$ & $96.31 \pm 1.08$ & $50.02 \pm 6.66$ & $1.13 \pm 0.06$ & $16: 84$ \\
& W0 & $5.96 \pm 1.08$ & $42.25 \pm 5.49$ & $91.79 \pm 1.79$ & $38.85 \pm 5.75$ & $1.03 \pm 0.04$ & $15: 85$ \\
P1 & W1 & $7.39 \pm 2.18$ & $55.48 \pm 13.83$ & $95.76 \pm 0.99$ & $53.22 \pm 13.82$ & $0.92 \pm 0.04$ & $14: 86$ \\
& W2 & $5.43 \pm 1.18$ & $37.34 \pm 8.31$ & $94.12 \pm 1.39$ & $35.22 \pm 8.21$ & $1.06 \pm 0.14$ & $13: 87$ \\
& W0 & $5.06 \pm 2.27$ & $40.12 \pm 17.24$ & $92.04 \pm 3.07$ & $3730 \pm 17.05$ & $0.97 \pm 0.08$ & $11: 89$ \\
P2 & W1 & $4.91 \pm 0.67$ & $36.29 \pm 1.67$ & $95.62 \pm 1.14$ & $34.71 \pm 2.00$ & $0.82 \pm 0.04$ & $24: 76$ \\
& W2 & $7.40 \pm 2.25$ & $43.17 \pm 8.52$ & $93.99 \pm 1.62$ & $40.66 \pm 8.67$ & $0.99 \pm 0.08$ & $24: 76$ \\
& P & $* *$ & $* *$ & $*$ & $*$ & $*$ & \\
\multirow{5}{*}{ Significance } & W & ns & ns & ns & ns & $*$ & \\
& PXW & ns & ns & ns & ns & $*$ & \\
\hline
\end{tabular}

Note : P0=Without DFM, P1=DFM ${ }_{A M S}, P 2=D F M_{R K}, W 0=0 \%$ HLM, W1 $=0.24 \%$ HLM, W2 $=0.48 \%$ HLM from DM concentrate, $\mathrm{NR}=$ Nitrogen Retentio, ND=Nitrogen Digestibility, $\mathrm{BV}=$ Biological Value, NNU=Net Nitrogen Utilization, DMI= Dry Matter Intake, $\mathrm{P}=$ Factor Use of DFM, W=Factor Level of HLM, PXW= DFM and HLM Interaction, ns=Non-significant, ARS=Ammoniated rice-straw, $C=$ Concentrate 
Table 3. Nitrogen Metabolism on different types of used Direct-fed Microbials (DFM)

\begin{tabular}{lccc}
\hline \multicolumn{1}{c}{ Variables } & P0 & P1 & P2 \\
\hline Consumption of N (g/d) & 16.22 & 14.98 & 15.43 \\
$\mathrm{~N}$ faeces (g/d) & 7.81 & 8.29 & 9.23 \\
$\mathrm{~N}$ urine $(\mathrm{g} / \mathrm{d})$ & 0.36 & 0.39 & 0.35 \\
$\mathrm{~N}$ ingested (g/d) & 8.41 & 6.69 & 6.21 \\
$\mathrm{~N}$ retention (g/day) & 8.06 & 6.30 & 5.85 \\
Retention Status (+/-) & + & + & + \\
Net Nitrogen Utilization (\%) & 49.92 & 42.43 & 37.56 \\
Biological Value (\%) & 95.53 & 93.89 & 93.88 \\
\hline
\end{tabular}

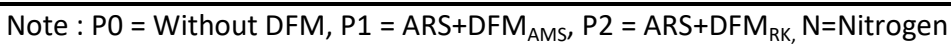

Increasing the level of HLM containing saponins at low doses has not been able to suppress protozoa so that the bacterial population is suppressed and this will cause a decrease in DMI. The addition of a higher level of HLM can suppress protozoa so that the bacterial population increases so that it can increase DMI again. This did not occur in sheep that were not given DFM in their feed which did not cause an increase in protozoa. A low dose of HLM alone can suppress protozoa so that the bacterial population increases; as a result the DMI would first increase then decrease because a high dose of HLM might poison both protozoa and bacteria. The microbial growth in the rumen is also affected by the presence of saponins, which may decrease the number of bacteria and fungi (Patra and Saxena. 2009).

Digestibility of crude protein is not sufficient to presented about feed efficiency, hence observation on $\mathrm{N}$ metabolism conducted to investigate the use of $\mathrm{N}$ through $\mathrm{N}$ retention percentage. Ranjhan (1977) stated that the observation of digestibility of crude protein that can be digested is not sufficient for the basis of evaluating the nutritional status of ruminants. The more important thing is to increase the amount of protein or $\mathrm{N}$ retention. Higher $\mathrm{N}$ retention represented higher utilization of $\mathrm{N}$ related with microbial protein synthesis on the rumen.

The use of DFM in this study decreased sheep nitrogen metabolism (Table 3 ) even the retention status for all treatment were positive.
It was attributed to the lower feed consumption in treatment than that of control (PO); hence, lower protein intake. Feed consumption and digestibility are influenced by nitrogen (Holmes and Wilson, 1984). Suryani et al. (2017) conducted a study which resulted in higher yields of nitrogen retention in control because it had a higher feed consumption. Meanwhile, feed consumption in treatment with DFM supplementation (P1 and P2), consumption of $N, N D$ and NR are lower than PO. If RN is low, it can be concluded that $\mathrm{N}$ utilization by sheep is low marked by high $\mathrm{N}$ released through urine. According to Puastuti et al. (2012), high N urine was related with ability to use $\mathrm{N}$ for microbial synthetic.

Seo et al. (2010) stated that the response of DFM used in ruminants was not all consistently positive as some results showed negative response. This is related to the level of DFM, the frequency of feeding and the feeding time, the microbes composition on DFM, the way of giving DFM, and the condition of animals. It was suspected that applied method by sprayed DFM on ARS and let them fermented for a night caused a bond between microbes and NPN contained in the ARS. Therefore, when ARS was consumed, this bond was difficult to release, resulting in failed fermentation and indigestible product which only passes the gastroinstestinal tract and excreted through faecal discharge. Table 3 showed the percentage of $\mathrm{N}$ on feaces was higher on the treatment with DFM supplementation. 
Table 4. Microbial protein synthesis on interaction between direct-fed microbials (DFM) and hibiscus leaf meal (HLM)

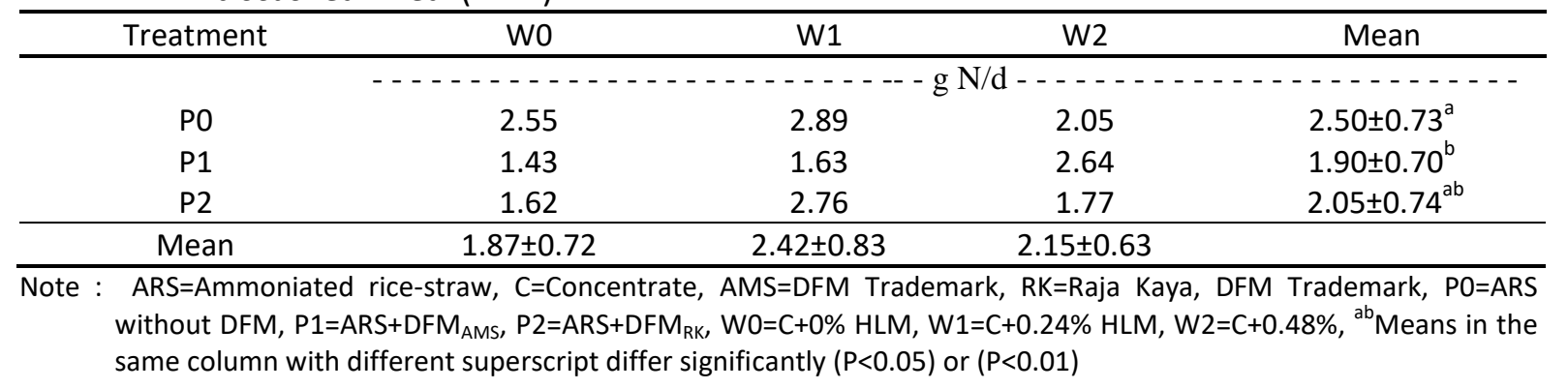

Banerjee (1978) stated that the nitrogen component which is part of $\mathrm{N}$ faeces is $\mathrm{N}$ feed which is not digested nor absorbed. According to Wina (2005), DFM for ruminants is generally combined with high-fiber and would increase dry matter consumption, dry matter digestibility, increase protein digestibility and nitrogen retention (Ngadiyono et al., 2001). The microbial composition contained in the two DFMs was not different, the difference is $D_{\text {DFM }}$ is dominated by Lactate Producing Bacteria and Bacillus sp., and $\mathrm{DFM}_{\mathrm{RK}}$ contained yeast $S$. Cereviseae. It is suspected that the response from DFM supplementation actually causes a decrease in the proteolytic bacterial population in the rumen, resulting in low $\mathrm{N}$ retention and high $\mathrm{N}$ excretion in urine.

The status of NR in this study was entirely positive, which means that all sheep experienced growth. The NR value states the nutritional status of animal feed (Kishan and Singh, 1980). Retention is an illustration of the use of proteins in the body and ability to provide their protein needs (Lloyd et al., 1978; Puastuti et al., 2012). Banerjee (1978) stated that if the $\mathrm{N}$ consumption was higher than excreted $\mathrm{N}$, it will make a positive NR status. Negative $N$ retention was happened if $N$ excreted was higher than $\mathrm{N}$ consumption.

\section{Microbial Protein Synthesis}

Microbial Protein Synthesis (MPS) and Efficiency of Microbial Protein Synthesis (EMPS) in the interaction of different DFM and HLM levels are presented in Table 4 and Table 5.

The results of the analysis of variance showed that there was a significant interaction $(P<0.01)$ between $P$ (DFM supplementation) and W (HLM level) on microbial protein synthesis (Table 4, Figure 1). Only DFM supplementation factor which have significant response $(P<0.05)$ on MPS. The interaction shows that the effect of DFM supplementation depends on the given of HLM level. These two factors influence each other on MPS and EMPS.

Figures 1 showed that P2 (DFM $\mathrm{RK})$ treatments of MPS increased and were optimal at HLM level of $0.25 \%$ resulted MPS $2.76 \mathrm{gN} / \mathrm{d}$, then it decreased together with increasment of HLM levels. According to Sniffen and Robinson (1987), microbial protein was contributed to the fulfillment of amino acids needed by livestock $40-80 \%$. Synthesis of microbial protein is closely related to $\mathrm{N}$ metabolism. $\mathrm{High} \mathrm{N}-\mathrm{NH}_{3}$ production will activate MPS if the energy provided is sufficient to increase the activity of enzymes produced by microbes (Ranjhan, 1977). The lower $N$ in urine and the higher nitrogen retention figure the higher the utilization of Nitrogen for MPS. In the P2 treatment, the MPS was increased from the start in line and supported with the high nitrogen metabolism. This is supported by consumption of N P2 which was higher than that of $\mathrm{P} 1$. 


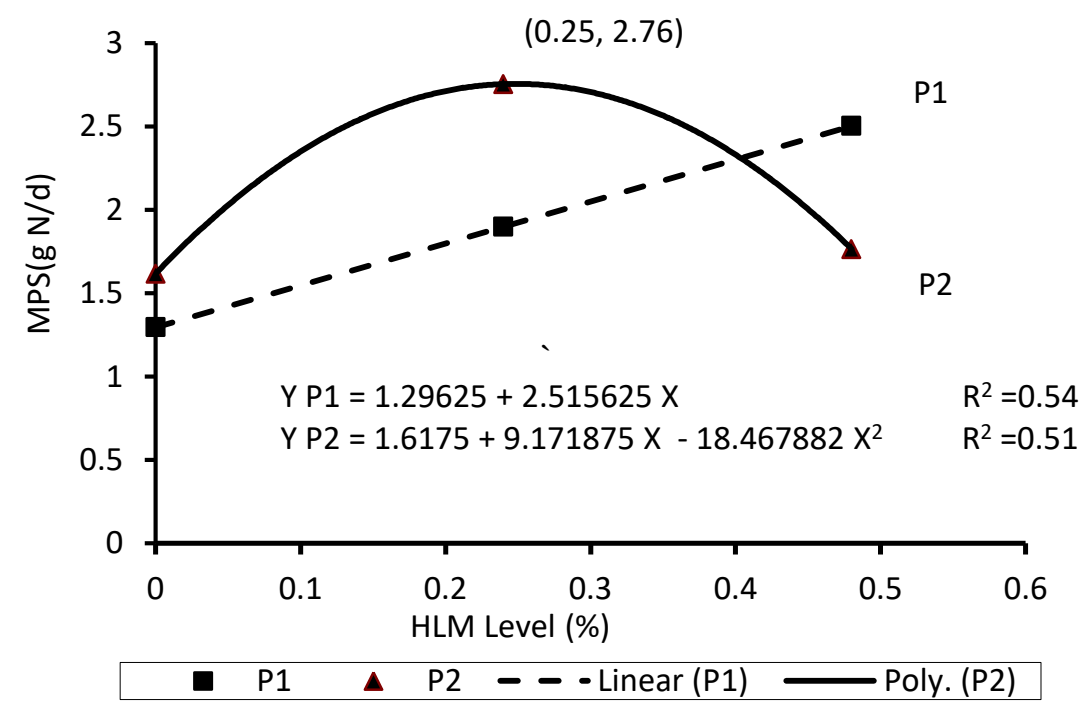

Figure 1. Interaction between Direct-fed Microbials (DFM) and Hibiscus Leaf Meal (HLM) on Microbial Protein Synthesis

In addition, this have occurred due to the stable condition of the rumen ecosystem with the use of HLM containing flavonoids as a buffer, so the ruminal fermentation runs optimally. After reaching the optimum point, the MPS was decreased together with the increasement of HLM levels. When the HLM level was increased, active substances that affect not only flavonoids, but also antimicrobial compounds and saponins which in high amounts have the potential to become toxins in the rumen ecosystem and affected bacterial population.According to Bata and Rahayu (2017), small types of Hibiscus leaves contain sulphonamide and piperonylamine compounds which are antimicrobial compounds. Wina et al., (2008) stated that some anti-nutritional compounds can be toxic, some of these compounds were antitrypsin, lectin, phytate, saponin, and forbolester. Decreased MPS also suspected caused by the role of $\mathrm{DFM}_{\mathrm{RK}}$ contains bacteria that have ability to release antimicrobial compounds named Sarcina lutea (Dawes and Holms, 1957), Lactobacilli (Azzaz et al., 2016), and Pseodomonas flourescens (Santoso et al., 2007). Allegedly there was a response due to these compounds poisoning bacteria and affected microbial populations in the rumen.

Oppositely, in treatment P1, the MPS decreases then increases with the increased HLM supplementation (Figures 1). This opposite interaction was caused by the different microbial compositions of the two DFM. Bacterial composition in DFM AMS $_{\text {was }}$ adapted to bioactive components contained in HLM and help maintained balance of ruminal ecosystem. According to Pathak (2008), the contributing factors to microbial protein synthesis (MPS) in the rumen are consumption of dry matter, percentage of feed protein, feed supply with fermentable energy, ratio of forage and concentrate in feed, rumen ecosystems, nitrogen synchronization and energy, length of feed stay in in the rumen, as well as vitamins and minerals.

The results of the analysis of variance showed a significant interaction $(P<0.01)$ between P (DFM supplementation) and W (HLM level) on efficiency of microbial protein synthesis (Table 5, Figure 2). The interaction shows that the effect of DFM supplementation depends on the given of HLM level. These two factors influence each other on EMPS. 
Table 5. Efficiency of microbial protein synthesis on interaction between direct-fed microbials (DFM) and hibiscus leaf meal (HLM)

\begin{tabular}{|c|c|c|c|c|}
\hline Treatment & WO & W1 & W2 & Mean \\
\hline & \multicolumn{4}{|c|}{ - - - - - - - - g N/kg DOMR/day - - - - - - - - - - } \\
\hline $\mathrm{PO}$ & 7.18 & 7.21 & 5.71 & $6.70 \pm 2.27$ \\
\hline P1 & 4.05 & 4.04 & 6.93 & $5.01 \pm 1.83$ \\
\hline $\mathrm{P} 2$ & 4.97 & 8.70 & 4.47 & $6.05 \pm 2.57$ \\
\hline Mean & $5.40 \pm 2.04$ & $6.65 \pm 2.90$ & $5.70 \pm 1$. & \\
\hline
\end{tabular}

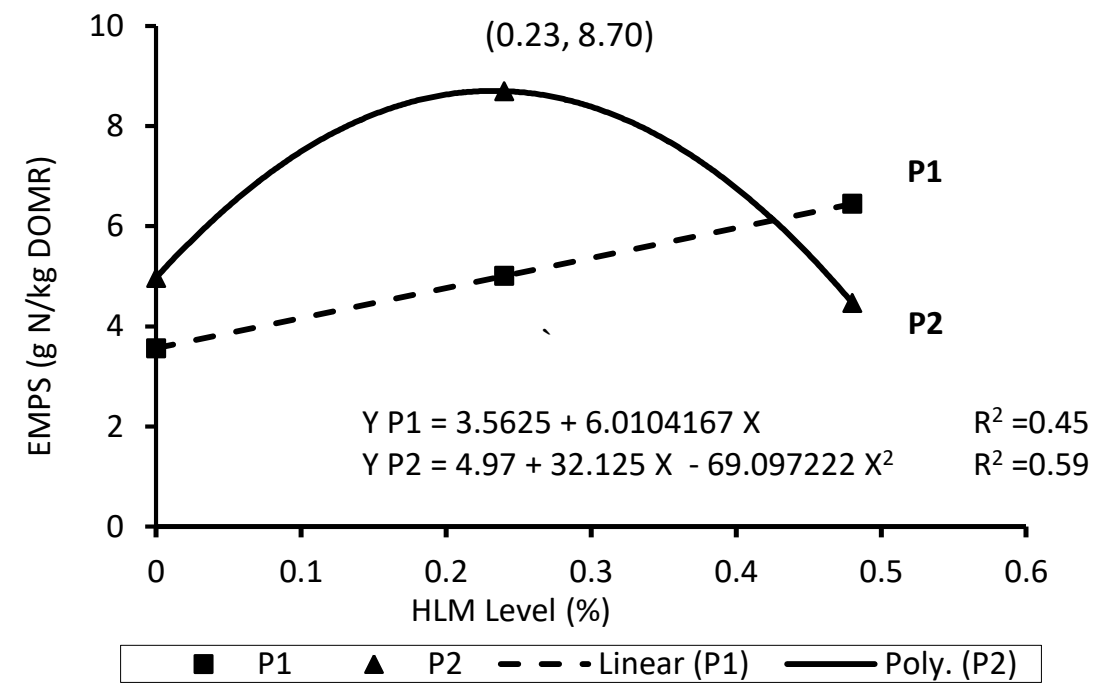

Figure 2. Interaction between Direct-fed Microbials (DFM) and Hibiscus Leaf Meal (HLM) on Efficiency of Microbial Protein Synthesis

Based on Table 5, the efficiency of optimal microbial protein synthesis was observed in the P2W1 treatment combination. Although further test showed that the highest MPS was achieved in POW1 treatment, its efficiency was achieved in the P2W1 treatment. This is influenced by the amount of fermented organic matter in the rumen (DOMR) (Table 6). Organic matter contained in feed is the main source of substrate for the development of microbes in the rumen, the amount of organic matter affects microbial production. Organic matter in the feed will be degraded by microbes into energy (Kurniawati, 2007). The DOMR produced in P2W1 treatment was lower than that in POW1, but the SPM produced was not significantly different. This shows the efficiency of using substrates in the P2W1 treatment is higher with for Microbial Protein Synthesis.
Determining the Efficiency of Microbial Protein Synthesis (EMPS) is influenced by several factors, including protein degradability and protein synchronization and feed energy. High protein degradability increases the amount of nitrogen for microbial protein synthesis if there is sufficient energy (McDonald et al., 2002). Crude protein is a component that mainly influences the amount of microbial protein synthesis production because CP provides N (Gosselink et al., 2003). Synchronization of protein and energy is highly important for Microbial Protein Synthesis forming. In the P2W1 treatment, the ability to use $\mathrm{N}$ digested was high as seen from the Biological Value of $95.65 \%$. Efficient protein and energy synchronization was achieved on P2W1 treatment. 
Table 6. Digestible organic matter fermented in the rumen, microbial protein synthesis, and efficiency of microbial protein synthesis between treatment

\begin{tabular}{|c|c|c|c|}
\hline Treatment & DOMR $(\mathrm{kg})$ & MPS (gN/d) & EMPS (gN/kg DOMR) \\
\hline POWO & 0.36 & $2.55^{\mathrm{ab}}$ & $7.18^{\mathrm{ab}}$ \\
\hline PoW1 & 0.42 & $2.89^{\mathrm{a}}$ & $7.21^{\mathrm{ab}}$ \\
\hline POW2 & 0.37 & $2.05^{\mathrm{ab}}$ & $5.71^{\mathrm{ab}}$ \\
\hline P1W0 & 0.36 & $1.43^{b}$ & $4.05^{b}$ \\
\hline P1W1 & 0.39 & $1.63^{\mathrm{ab}}$ & $4.04^{b}$ \\
\hline P1W2 & 0.38 & $2.64^{\mathrm{ab}}$ & $6.93^{\mathrm{ab}}$ \\
\hline P2W0 & 0.32 & $1.62^{\mathrm{ab}}$ & $4.97^{\mathrm{ab}}$ \\
\hline P2W1 & 0.32 & $2.76^{\mathrm{ab}}$ & $8.70^{a}$ \\
\hline P2W2 & 0.40 & $1.77^{\mathrm{ab}}$ & $4.47^{\mathrm{ab}}$ \\
\hline
\end{tabular}

Information : P=Ammoniated rice-straw, $\mathrm{W}=$ Concentrate, AMS=DFM Trademark, RK=Raja Kaya, DFM Trademark, HLM = Hibiscus Leaf Meal, POW0=Without DFM $+0 \% H L M$, POW1=Without DFM+0.24\%HLM, POW2=Without DFM + $0.48 \% \mathrm{HLM}, \mathrm{P} 1 \mathrm{~W} 0=\mathrm{DFM} \mathrm{AMS}_{\mathrm{A}}+0 \% \mathrm{HLM}, \mathrm{P} 1 \mathrm{~W} 1=\mathrm{DFM}_{\mathrm{AMS}}+0.24 \% \mathrm{HLM}, \mathrm{P} 1 \mathrm{~W} 2=\mathrm{DFM}_{\mathrm{AMS}}+0.48 \% \mathrm{HLM}$, $\mathrm{P} 2 \mathrm{~W} 0=\mathrm{DFM}_{\mathrm{RK}}+0 \% \mathrm{HLM}, \mathrm{P} 2 \mathrm{~W} 1=\mathrm{DFM}_{\mathrm{RK}}+0.24 \% \mathrm{HLM}, \mathrm{P} 2 \mathrm{~W} 2=\mathrm{DFM}_{\mathrm{RK}}+0.48 \% \mathrm{HLM},{ }^{\mathrm{ab}}$ Means in the same column with different superscript differ significantly $(P<0.05)$, DOMR=Digestible Organic Matter Fermented in the Rumen, MPS=Microbial Protein Synthesis, EMPS=Efficiency of Microbial Protein Synthesis

Based on Figure 2, at a dose of $0.23 \% \mathrm{HLM}$, bioactivity in hibiscus/waru leaves either as a defaunation agent or rumen $\mathrm{pH}$ buffer was able to maintain the condition of the rumen in balance along with the microbes contained in $D_{\text {DF }}$. Defaunation using natural ingredients does not eliminate the entire protozoa population, but is effective in controlling the population in normal numbers (Sutardi, 1992). Sairullah et al. (2016) stated that saponin increases microbial protein synthesis by decreasing protein degradation in the rumen. The decrease in rumen protein degradation is caused by the formation of a slightly digestible protein-saponin complex compound.

\section{Conclusions}

The use of HLM without DFM suplementation resulted in a positive impact on $\mathrm{N}$ Metabolism. The combination of $0.23 \%$ HLM and $D_{F M}$ resulted in the most efficient Microbial Protein Synthesis

\section{REFERENCES}

AOAC. 2005. Official Methods of Analysis of the Association of Analytical Chemists International. $18^{\text {th }}$ ed. MD U.S.A Official methods, Gathersburg.

Azzaz, H. H., T. A. Morsy, and H. A. Murad. 2016. Microbial Feed Enhancement Supplements for Ruminant 's Performance Enchacement. Asian J. Agric. Res. 10:1-14.
Balcells, J., A. Aris, A. Serrano, A. R. Seradj, J. Crespo, and M. Devant. 2012. Effects of an extract of plant flavonoids (Bioflavex) on rumen fermentation and performance in heifers fed high-concentrate diets. J. Anim. Sci. 90:49754984.

Banerjee, G. C. 1978. Animal Nutrition. Oxford \& IBM Pub.Co Calcutta.

Bata, M., and S. Rahayu. 2017. Evaluation of Bioactive Substances in Hibiscus tiliaceus and its Potential as a Ruminant Feed Additive. Bentham Sci. 13:157-164.

Bata, M., S. Rahayu, and N. Hidayat. 2016. Performan Sapi Sumba Ongole (SO) yang Diberi Jerami Padi Amoniasi dan Konsentrat yang Disuplementasi dengan Tepung Daun Waru (Hibiscus tiliaceus). Agripet. 16:106-113.

Bradford, M. M. 1976. A Rapid and Sensitive Method for the Quantitation of Microgram Quantities of Protein Utilizing the Principle of Protein-Dye Binding. Anal. Biochem. 72:248-254.

Buntyn, J. O., T. B. Schmidt, D. J. Nisbet, and T. R. Callaway. 2015. The Role of Direct-Fed Microbials in Conventional Livestock Production. Annu. Rev. Anim. Biosci. 4:335-355.

Chen, X. B., and M. J. Gomes. 1995. Estimation of Microbial Protein Supply to Sheep and Cattle Based on Urinary Excretion of Purine Derivatives - an Overview of the Technical Details. Int. Feed Resour. Unit. 1-21.

Cole, H. H., and M. Ronning. 1974. Animal Agricultural. The Biology of Domestic Animals and Their Use by Man. W.H. Freeman \& Co., San Fransisco.

Dawes, E. A., and W. H. Holms. 1957. Metabolism of Sarcina Lutea. J. Bacteriol. 75:390-399.

Ditjennak. 2018. Statistik Peternakan dan Kesehatan Hewan. Jakarta. 
Elghandour, M. M. Y., A. Z. M. Salem, J. S. M. Castañeda, L. M. Camacho, A. E. Kholif, and J. C. V. Chagoyán. 2015. Direct-Fed Microbes: A Tool for Improving the Utilization of Low Quality Roughages in Ruminants. J. Integr. Agric. 14:526533.

Ghorbani, G. R., D. P. Morgavi, K. A. Beauchemin, and J. A. Z. Leedle. 2018. Effects of Bacterial Direct-Fed Microbials on Ruminal Fermentation, Blood Variables and the Microbial Populations of Feedlot Cattle. J. Anim. Sci. 80:1977-1985.

Gosselink, J. M. ., C. Poncet, J. . Dulphy, and J. . Cone. 2003. Stimation of Duodenal Flow of Microbial Nitrogen in Ruminants Based on The Chemical Composition of Forage: A Literature Review. Anim. Res. EDP Sci. 52:229-243.

Hanum, Z., and Y. Usman. 2011. Analisis Proksimat Amoniasi Jerami Padi dengan Penambahan Isi Rumen. Agripet. 11:39-44.

Hartadi, H., S. Reksohadiprodjo, and A. D. Tillman. 2017. Tabel Komposisi Pakan untuk Indonesia. 6th ed. Gadjah Mada University Press, Yogyakarta.

Holmes, C. W., and G. F. Wilson. 1984. Milk Production from Pasture. Butterworths Agric.Book, Wellington New Zealand.

Kalantar M. 2018. The Importance of Flavonoids in Ruminant Nutrition. Arch Animal Husb \& Dairy Sci. 1(1): 1-4. AAHDS.MS.ID.000504.

Khan MA, M Sarwar, M Nisa and MS Khan. 2004. Influence of enzose on feeding value of urea treated corncobs in lactating crossbred cows. Asian-Aust. J. Anim. Sci. 17:70-74.

Khan, R. U., S. Naz, K. Dhama, K. Karthik, R. Tiwari, M. M. Abdelrahman, I. A. Alhidary, and A. Zahoor. 2016. Direct-Fed Microbial: Beneficial Applications, Modes of Action and Prospects as A Safe Tool for Enhancing Ruminant Production and Safe Guarding Health. J. Int. Pharmacol. 12:220-231.

Kishan, J., and U. B. Singh. 1980. Relationship Between Nitrogen Intake and Excretion in Cattle and Buffaloes Fed Different Fodders. Indian J. Anim. Sci. 50:128-130.

Krehbiel, C. R., S. R. Rust, G. Zhang, and S. E. Gilliland. 2003. Bacterial Direct-Fed Microbials in Ruminant Diets: Performance Response and Mode of Action. J. Anim. Sci. 18:120-132.

Kurniawati, A. 2007. In-vitro Gas Production Technic for feed evaluation: Gas Volume and feed digestion J. IIm. Apl. Isot. dan Radiasi. 3:40-49.

Lloyd, L. E., B. E. McDonald, and E. W. Crampton. 1978. Fundamentals of Nutrition. $2^{\text {nd }}$ ed. W.H. Freeman and Co., Reading, UK.

McAllister, T. A., K. A. Beauchemin, A. Y. Alazzeh, J. Baah, R. M. Teather, and K. Stanford. 2011.
Review: The Use of Direct Fed Microbials to Mitigate Pathogens and Enhance Production in Cattle. Can. J. Anim. Sci. 91:193-211.

McDonald, P., R. . Edwards, and J. F. . Greenhalgh. 2002. Animal Nutrition. $6^{\text {th }}$ ed. New York.

Mutaqin, B.K., Tanuwiria, U.H., Hernawan, E. 2018. Invitro Study on the Fluid From Banana Stem Bioprocess as Direct Fed Microbial. In: IOP Conf. Series : Earth Environ. Sci. Vol. 119. Pp. 1-7.

Ngadiyono, N., H. Hartadi, M. Winugroho, D. D. Siswansyah, and S. N. Ahmad. 2001. Pengaruh Pemberian Bioplus terhadap Kinerja Sapi Madura di Kalimantan Tengah. JITV. 6:69-75.

Pathak, A. K. 2008. Various Factors Affecting Microbial Protein Synthesis in the Rumen. Vet. World. 1:186-189.

Patra, A., and J. Saxena. 2009. The Effect and Mode of Action of Saponins on the Microbial Populations and Fermentation in the Rumen and Ruminant Production. Nutr. Res. Rev. 22:204219.

Puastuti, W., D. Yulistiani, and I.-W. Mathius. 2012. Respon Fermentasi Rumen dan Retensi Nitrogen dari Domba yang Diberi Protein Tahan Degradasi dalam Rumen. JITV. 17:67-72.

Putra, D., L. M. Yustiati, and R. Utomo. 2016. Estimasi Sintesis Protein Mikrobia Rumen Menggunakan Ekskresi Derivat Purin dalam Urin dengan Teknik Spot Sampling pada Kambing Bligon dan Kambing Kejobong. Bultein Pet. 40:178-186.

Ranjhan, S. K. 1977. Animal Nutrition and Feeding Practices in India. (F. A. O. of the UN, editor.). Vikas Pub. House, New Delhi.

Sairullah, P., S. Chuzaemi, and H. Sudarwati. 2016. Effect of Flour and Papaya Leaf Extract (Caricapapaya L.) in Feed to Ammonia Concentration, Volatile Fatty Acids and Microbial Protein Synthesis in Vitro. J. Ternak Trop. 17:6673.

Santoso, S. E., L. Soesanto, and T. A. D. Haryanto. 2007. Penekanan Hayati Penyakit Moler pada Bawang Merah dengan Trichoderma harzianum, Trichoderma koningii, dan Pseudomonas P60. J. HPT Trop. 7:53-61.

Seo, J. K., S. W. Kim, M. H. Kim, S. D. Upadhaya, D. K. Kam, and J. K. Ha. 2010. Direct-Fed Microbials for Ruminant Animals. Asian Aust. J. Anim. Sci. 23:1657-1667.

Seradj AR, Abecia L, Crespo J, Villalba D, Fondevila M, Balcells J (2014) The effect of Bioflavex ${ }^{\circledR}$ and its pure flavonoid components on in vitro fermentation parameters and methane production in rumen fluid from steers given high concentrate diets. Anim Feed Sci Technol 197: 85-91. 
Sniffen, C. J., and P. H. Robinson. 1987. Microbial Growth and Flow as Influenced by Dietary Manipulations. J. Dairy Sci. 70:425-441.

Steel, R. G. D., and J. H. Torrie. 1991. Prinsip dan Prosedur Statistika Suatu Pendekatan Biometrik. (B. Sumantri, editor.). PT. Gramedia, Jakarta.

Suryani, H., M. Zain, R. W. S. Ningrat, and N. Jamarun. 2017. Effect of Dietary Supplementation Based on an Ammoniated Palm Frond with Direct-Fed Microbials and Virgin Coconut Oil on The Growth Performance and Methane Production of Bali Cattle. Pak. J. Nutr. 16:599-604.
Sutardi. 1992. Pengembangan Pakan Ternak Ruminansia. In: Seminar Nasional Bidang Peternakan. Bogor. Pp. 52-76.

Tukey, J. W. 1953. The Problem of Multiple Comparisons, 1953, Princeton University. New Jersey.

Wina, E. 2005. Teknologi Pemanfaatan Mikroorganisme dalam Pakan untuk Meningkatkan Produktivitas Ternak Ruminansia di Indonesia; Sebuah Review. J. War. 15:173-186.

Wina, E., I. W. . Susana, and T. Pasaribu. 2008. Pemanfaatan Bungkil Jarak Pagar (Jatropha curcas) dan Kendalanya sebagai Bahan Pakan Ternak. Wartazoa. 18:1-8. 